\section{Correcting Loss of the Terminal Bud in Fraser Fir Christmas Trees}

\author{
L. Eric Hinesley ${ }^{1}$ and Layne K. Snelling ${ }^{2}$ \\ Department of Horticultural Science, North Carolina State University, Raleigh, \\ NC 27695-7609
}

Additional index words. Abies fraseri

\begin{abstract}
Various pruning treatments were evaluated to determine the best procedure to correct terminal bud loss in Fraser fir [Abies fraseri (Pursh) Poir.]. Removing the top node (expanding terminal and subterminal buds) soon after budbreak combined with light pruning of the major branches in the next two lower whorls best restored a normal leader. This procedure allowed one or more shoots just below the cut to become orthotropic leaders in the first growing season. All but one of these shoots were removed, and only a single leader was retained after growth matured in late August or September.
\end{abstract}

Loss of the central leader in a Christmas tree increases the incidence and severity of defects in the crown (e.g., uneven density, gaps or open tiers, asymmetry, and trunk sweep). Defects reduce the value of a Christmas tree or make it unsaleable.

Fraser fir, a valuable Christmas tree species, is usually established in the field as a 5year-old transplant. A normal leader is orthotropic and subtended by four to seven nodal branches (Fig. 1A). For unknown reasons, terminal buds sometimes abort at the beginning of the first growing season in the field (Fig. 1B, cross-hatched bud). Other causes (frost in early spring, mechanical damage during transplanting, insect foraging, and breakage by animals and birds) also can leave plants sequently, trees lose their straight central axis and symmetry; hence, a new leader must be trained. Despite many opinions about how to remedy this problem, to our knowledge no systematic study has been reported. Our objective was to test several procedures for correcting loss of the terminal bud in Fraser fir.

\section{Materials and Methods}

Definition of terms. "Trunk sweep" means that the stem is bowed or is vertical but offset from the center axis of the crown. "Offset" is the horizontal distance of the terminal bud from the center axis of the tree (Fig. 2A). "Angle from vertical" is the angle (in degrees) between the center axis (vertical stem) and a

Received for publication 10Feb. 1994. Accepted for publication 8 Nov. 1994. This research was funded by the North Carolina Agricultural Research Service, Raleigh. Technical assistance by Danny Roten and Jeff Hartsog (Upper Mountain Research Station, Laurel Springs, N.C.) is gratefully acknowltransplants. The cost of publishing this paper was defrayed in part by the payment of page charges. Under postal regulations, this paper therefore must be hereby marked advertisement solely to indicate this fact.

${ }^{1}$ Professor.

${ }^{2}$ Research Technician. without a terminal bud or central leader. Conedged. The North Carolina Forest Service provided line from the terminal bud of the best leader to its insertion point on the stem. For example, a horizontal branch 10 units in length has offset $=10$ units and the angle from vertical $=90^{\circ}$; for an orthotropic leader (Fig. 1A), offset $=0$ and the angle from vertical $=0^{\circ}$. "Shearing," usually done with a knife or machine in July or August, is the pruning that shapes and thickens the crown of a Christmas tree. The terms "tip" or "lightly prune" signify removal of the apex or distal end (terminal and subterminal buds) of a branch. This procedure is confined to the tip of a branch, whereas shearing often removes a greater portion of the branch.
Pruning method only (Expt. 1, 1991). A site was prepared in an old pasture (Upper Mountain Research Station, Laurel Springs, N.C.; elevation $=1030 \mathrm{~m}$ ) during Fall 1989 by subsoiling $($ depth $=0.6 \mathrm{~m})$ in rows $($ spacing $=$ $1.4 \mathrm{~m})$, followed by tilling ( 0.8 -m-wide strips) to a depth of 10 to $15 \mathrm{~cm}$. Triple superphosphate and dolomitic lime were incorporated during tilling to bring fertility and $\mathrm{pH}$ to recommended levels for Christmas trees (Shelton, 1983). The soil was a Watauga loam (Typic Hapludult, fine-loamy, micaceous, mesic).

On 4 Sept. 1990, uniform Fraser fir transplants ( 3 years as seedlings and 3 years as transplants; height, $\approx 0.6 \mathrm{~m}$ ) were dug from the N.C. Forest Service Nursery, Crossnore. They were planted at Laurel Springs the next day ( spacing $=1.5 \mathrm{~m})$ and irrigated with overhead sprinklers immediately after planting and as needed thereafter.

On 27 Mar. 1991, ₹5 weeks before budbreak, the terminal bud was removed from each plant, except on those trees designated as controls (treatment 1).

Eight pruning treatments, including the control (Table 1), were used during the 1991 growing season. The design was a randomized complete block with 25 blocks (replications). Each plant was one replication of a treatment.

After the first growing season, plants were measured for leader elongation, diameter of best leader $3 \mathrm{~cm}$ above insertion point or origin, leader angle from the vertical axis (Fig. 2A), number of lateral branches bending upward to become leaders, number of subtermi-

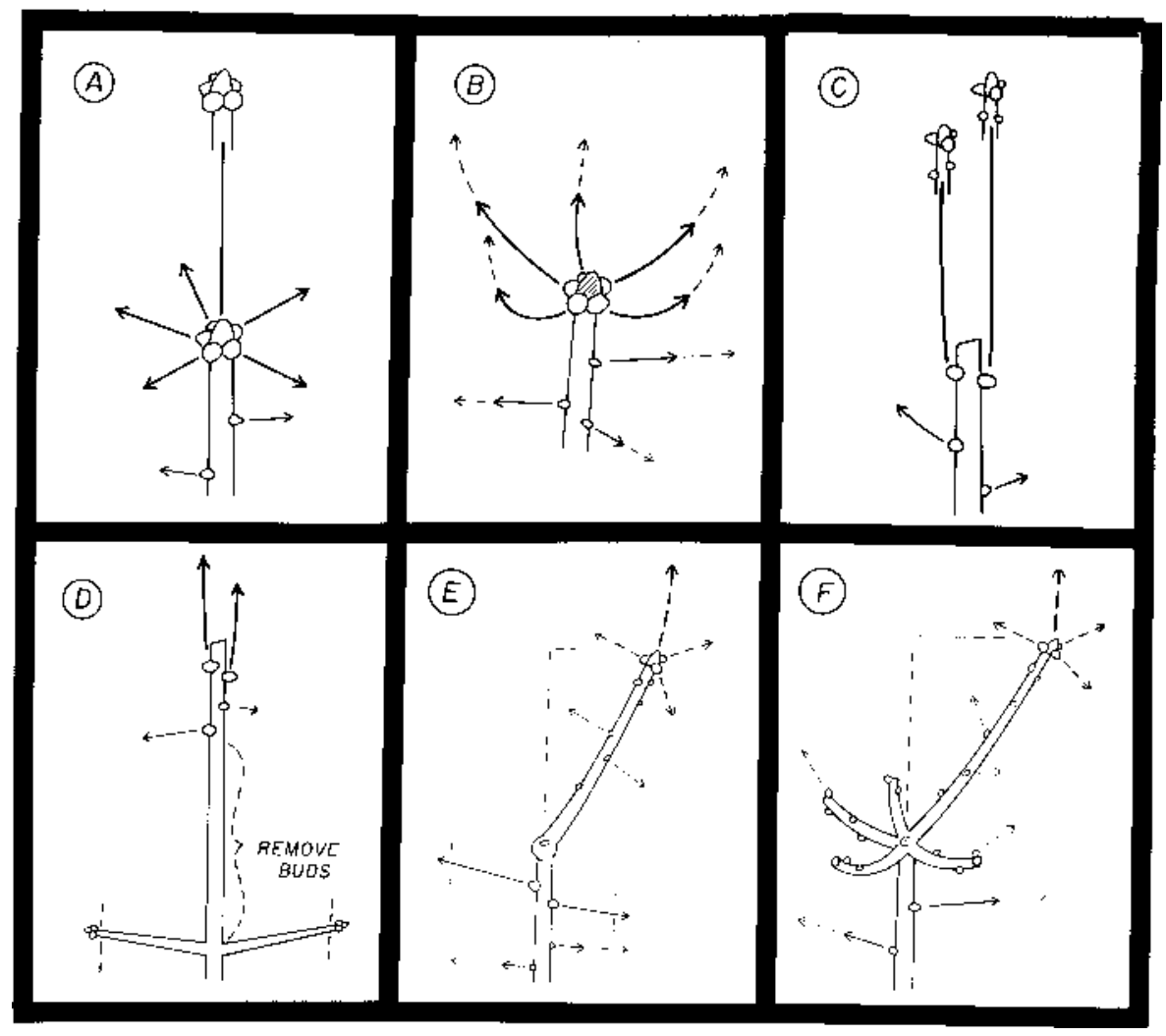

Fig. 1. Pruning treatments used to correct loss of the terminal bud in Fraser fir Christmas trees. Arrows indicate direction of shoot growth following treatment; broken arrow is for second year. Panels $\mathbf{E}$ and F depict plants one growing season after treatment. (A) Treatment 1; (B) treatment 2; (C) treatment 3A; (D) treatment 3B; (E) treatment 5; (F) treatment 4A. Treatments are described in Table 1. 


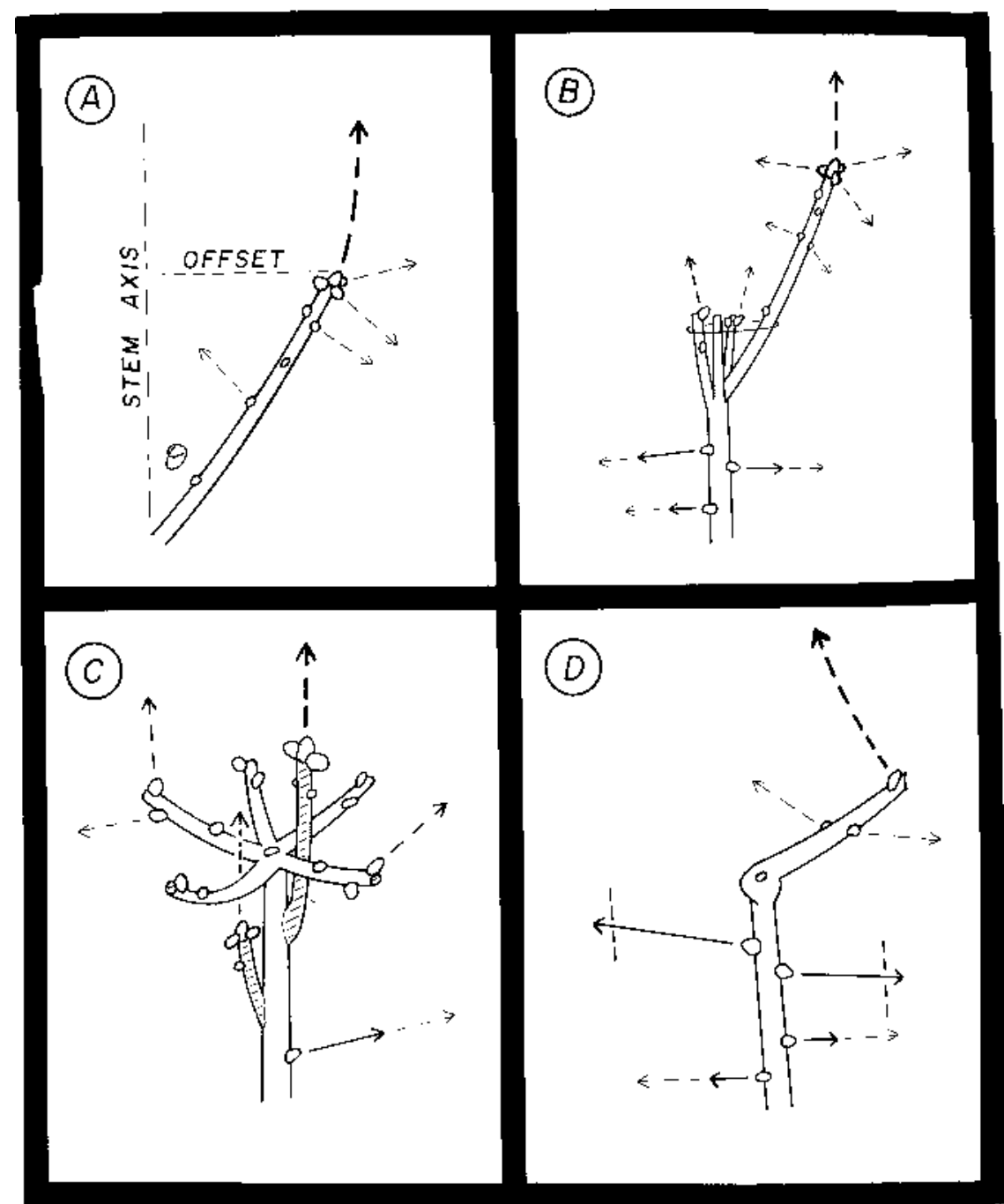

Fig. 2. Pruning treatments used to correct loss of the terminal bud in Fraser fir Christmas trees. Plants are depicted one growing season after treatment. Broken arrows indicate shoot growth the second year. (A) Branch bending up to make a leader after the first growing season. Angle (theta) is measured from vertical, and offset is the horizontal distance from the center, vertical axis to the terminal bud. (B) Treatment 4B, Expt. 1; (C) treatment 6, Expt. 1; (D) treatment 6, Expt. 2. Treatments are described in Tables 1 and 2 .

Table 1. Treatments used to correct loss of the terminal bud in Fraser fir transplants (Expt. 1).

\begin{tabular}{ll}
\hline \hline Treatment & Description \\
\hline 1 & Kept terminal bud; no pruning required. \\
2 & $\begin{array}{c}\text { Removed terminal bud; no pruning in the first growing season; before second growing } \\
\text { season, all branches removed from the apical whorl except the one with the smallest } \\
\text { angle from the vertical. }\end{array}$
\end{tabular}

3A Removed apical node when new growth was 1 to $2 \mathrm{~cm}$ long; tipped ${ }^{2}$ major branches in 1- and 2-year-old branches; retained only one orthotropic leader in late summer.

3B Similar to treatment 3A but initially retained only four or five lateral buds on the upper half of leader (1990 internode).

Pruned when elongation was almost complete but not hardened (27 June 1991)

Retained one nonpruned current-year branch in top whorl (1990 node) to become a leader; shortened other current-year branches in top whorl to about half-length; tipped $^{2}$ major branches in 1- and 2-year-old whorls.

4B Similar to treatment 4A; tied the lateral branch in a vertical position using the other current-year branch stubs as supports.

5 Retained one nonpruned current-year branch in the top whorl (1990 node) to become a leader; removed other branches in the top whorl; tipped ${ }^{z}$ major branches in 1- and 2-year-old whorls.

6 Pruned all current-year branches in top whorl (1990 node) to about one-third the original length; tipped ${ }^{z}$ major branches in 1- and 2-year-old whorls. In late summer, pruned to favor the most promising bud or sideshoot as a leader. For some plants, removed the residual 1990 whorl if a vertical sideshoot or bud just below it developed as a leader. Removed extra vertical leaders.

${ }^{2}$ Signifies removal of only the terminal and subterminal buds on a branch. nal buds on the best leader, and leader symmetry. If a tree had no orthotropic leader, measurements were made on the lateral branch most likely to make a replacement leader (i.e., with the smallest angle from the vertical axis). A shoot was classified as a vertical leader if it was orthotropic with radial needle symmetry. Symmetry was rated as follows: $0.0=$ tworanked foliage and greater frequency of buds on the adaxial side, $1.0=$ radial distribution of foliage and buds (as on a leader), $0.5=$ intermediate.

Treatment 2 was to receive no corrective pruning the first year, but the treatment was lost owing to an error in pruning. Commercially, such trees would normally receive corrective pruning in July or August.

Trees were first sheared after the 1992 growing season. After the third year, height was measured, and each tree was evaluated for defects. A quality rating ( $1=$ poor; $3=$ average; $5=$ excellent) was assigned to each tree.

Data were subjected to analysis of variance, and means were separated by Duncan's multiple range test at $P \leq 0.05$, using SAS procedures (SAS Institute, 1990).

Method and time of pruning (Expt. 2, 1992). This experiment was performed for two primary reasons. It included three pruning dates, thus allowing inferences about the effect of shearing date on replacement leader development, and it included a group of plants (treatment 2) that lost the terminal bud and received no corrective pruning during the first growing season (originally intended as one of two control treatments in Expt. 1). Such trees eventually make new leaders but often with more trunk sweep than trees subjected to corrective pruning or mechanical straightening. This adaptation translates into more offset of the leader from the center axis, leader symmetry more like that of a branch, a higher percentage of trees needing corrective pruning or mechanical straightening in the top, and more difficulty in shaping a symmetrical crown.

Fraser fir transplants were dug at Crossnore on 19 Aug. 1991, graded for uniformity, and planted adjacent to Expt. 1 the following morning. Procedures, site preparation, experimental design, cultural practices, data collection, and data analysis were similar to Expt. 1.

Ten pruning treatments were used during the 1992 growing season (Table 2). Height and leader attributes were measured after the first and second growing seasons.

\section{Results and Discussion}

Most vegetative buds on a Fraser fir branch are on the adaxial side, with the most buds toward the distal end (tip) similar to balsam fir (Abies balsamea L.) (Powell, 1982). When a branch curves upward to become a leader, the paucity or absence of buds on the abaxial side causes a gap or uneven crown density. On young trees, gaps in the crown normally fill in over time if tree vigor (bud density and elongation) is good and shoot growth is restrained by shearing.

As expected, the best leaders were on normal plants that did not lose the terminal bud 
(Tables 3 and 4; treatment 1; Fig. 1A). These leaders were straight with negligible sweep (offset was about zero) and had radial symmetry, radial distribution of buds, and more subterminal buds.

After the first growing season, plants that received no corrective pruning (treatment 2 , Fig. 1B) had leaders (upturning branches) averaging $54^{\circ}$ from the vertical axis, and $84 \%$ still had symmetry more like branches than leaders (Table 4 , symmetry $=0.16$ ). During the first growing season, current-year branches in the apical node began to compete for dominance in the absence of a true leader. The most dominant branch eventually became the replacement leader. To encourage faster straightening of the replacement leader, other branches in the apical node were removed before the second growing season. Twenty-two percent of these plants had no true leader after the second year (Table 5, symmetry $=0.78$ ). Following the third year, all plants in treatment 2 had orthotropic leaders, radial bud and needle symmetry, and a mean offset of $5 \mathrm{~cm}$ from the center axis of the tree (data not shown).

Table 2. Treatments to correct loss of the terminal bud in Fraser fir transplants (Expt. 2).

\begin{tabular}{|c|c|}
\hline Treatment & Description \\
\hline$\overline{1}$ & Same as treatment 1 , Expt. $1 .^{z}$ \\
\hline 2 & Same as treatment 2, Expt. $1 .^{z}$ \\
\hline \multicolumn{2}{|c|}{ Pruned soon after budbreak (21 May 1992) } \\
\hline $3 \mathrm{~A}$ & Similar to treatment $3 \mathrm{~A}$, Expt. $1 .^{\mathrm{z}}$ \\
\hline 3B & Similar to treatment $3 \mathrm{~B}$, Expt. $1 .^{\mathrm{z}}$ \\
\hline \multicolumn{2}{|c|}{$\begin{array}{l}\text { Pruned when shoot elongation was almost } \\
\text { complete, but not hardened ( } 2 \text { July 1992) }\end{array}$} \\
\hline $4 \mathrm{~A}$ & Similar to treatment $4 \mathrm{~A}$, Expt. $1 .^{\mathrm{z}}$ \\
\hline 5 & Similar to treatment 5 , Expt. $1 .^{z}$ \\
\hline 6 & $\begin{array}{l}\text { Similar to treatment } 5 \text {; shortened the } \\
\text { residual branch to a bud on the upper } \\
\text { (adaxial) side at about one-half } \\
\text { to two-thirds the original length. }\end{array}$ \\
\hline \multicolumn{2}{|c|}{$\begin{array}{c}\text { Pruned late in the growing season after shoots } \\
\text { were mature (31 July 1992) }\end{array}$} \\
\hline I & Same as treatment $4 \mathrm{~A}$. \\
\hline 8 & Same as treatment 5. \\
\hline 9 & Same as treatment 6. \\
\hline
\end{tabular}

${ }^{\mathrm{z}}$ Described in Table 1.
Removing the apical whorl shortly after budbreak (Tables 3 and 4; treatments $3 \mathrm{~A}$ and 3B) usually induced one to three orthotropic leaders (mean offset $=2.2 \mathrm{~cm}$, symmetry $=$ 0.90 ) from lateral shoots or buds just below the cut (Fig. $1 \mathrm{C}$ and D). These leaders were shorter than normal, especially in Expt. 2, with a smaller diameter and fewer subterminal buds. Except removing all but one of these vertical shoots, no additional pruning was needed to produce a good-quality Christmas tree.

Treatments with minimal trunk sweep (offset) were those that induced an orthotropic leader in the first growing season. Where a branch became a replacement leader, the resulting sweep was usually small enough to be a minor defect [U.S. Dept. of Agriculture (USDA), 1989]. Trunk sweep was low on the stem and probably would be hidden when trees reached marketable size ( $2 \mathrm{~m}$ in height) in 4 to 5 years. Losing the terminal bud in an older tree more likely would result in a noticeable bend or offset in the upper crown if a branch were allowed to become the new leader. When the visible offset is 10 to $15 \mathrm{~cm}$ from the center axis, it is a minor defect (USDA, 1989). If offset exceeds $15 \mathrm{~cm}$, the tree is classified as a cull, regardless of other traits.

In Expt. 1, treatments that retained a branch in the top whorl (Table 3; treatments 4A, 4B, and 5) had leaders averaging $29^{\circ}$ to $36^{\circ}$ from vertical after the first year, and more than half had developed radial needle and bud symmetry at the distal end. Despite being offset (Fig. 2A), the apex of most leaders was oriented upward to produce a normal vertical leader the second year. Recovery was slower in Expt. 2, and angles were greater than in Expt. 1; some trees still had no orthotropic leader after the second year (i.e., offset $>0.0 \mathrm{~cm}$ ) (Table 5).

Treatment 4B (Expt. 1, Fig. 2B) used current-year branch stubs in the top whorl as supports for the one branch that was tied upright. In addition to being tedious, it resulted in the development of one or two adventitious buds on the cut surface at the distal end of many branch stubs. With branch stubs in an upright position, these buds developed strongly and apparently reduced the vigor (diameter growth) of the nonpruned branch that was tied up as the leader (Table 3; treatment 4A vs. treatment $4 \mathrm{~B}$ ). Without removing branch stubs before the following growing season, these buds would have made vertical leaders, thus requiring more corrective pruning.

In conventional practice, branch stubs are often used to tie up a branch late in the growing season. No adventitious buds form on the more mature branch stubs, but lateral buds already present can strengthen and often develop into vertical shoots the next year. This problem can be avoided by rubbing off the buds when the stubs are first tied up.

Treatment 5 (Fig. 1E, Table 1) removed all but a single, nonpruned, current-year branch in the upper node, which was left to become a leader. This branch later exhibited some compensatory growth, but there were no other residual branches in the node to fill the crown, such as in treatment 4A (Fig. 1F). This pattern led to noticeable gaps or uneven density in the crown. The ultimate effect on tree quality is unknown.

Treatment 3B (Fig. 1D, Table 1) removed the apical bud cluster soon after budbreak and left four or five lateral buds on the upper part of the 1-year-old internode subtending the apical bud cluster. Although this method yielded an orthotropic leader on most plants, it also produced an open tier in the crown-a potential defect. The rationale was that current-year leader growth in 1991 might be stronger if the potential growth were divided among fewer growing points on the subtending (1990) internode. Actually, the opposite occurred; leaders in treatment $3 \mathrm{~B}$ were significantly thinner than those in treatment 3A (Table 3). The number of lateral shoots on the 1990 internode apparently influenced leader development in 1991. Auxin from buds stimulates growth and makes a branch or leader more competitive for available nutrients and water (Little, 1970). Removing buds, as in treatment $3 \mathrm{~B}$, is not recommended.

In Treatment 6 of Expt. 1 (Fig. 2C, Table 1), all current-year branches in the top whorl (1990 node) were cut to about one-third their full length. These plants had no obvious re-

Table 3. Leader traits of Fraser fir one growing season after removal of the terminal bud (Expt. 1).

\begin{tabular}{|c|c|c|c|c|c|c|c|c|c|}
\hline Treatment $^{\mathrm{v}}$ & $\begin{array}{c}\text { With } \\
\text { leaders } \\
(\%)\end{array}$ & $\begin{array}{c}\text { No. } \\
\text { leaders }\end{array}$ & $\begin{array}{l}\text { Length }^{\mathrm{z}} \\
(\mathrm{cm})\end{array}$ & $\begin{array}{c}\text { Angle } \\
\left(^{\circ}\right)\end{array}$ & $\begin{array}{c}\text { Offset } \\
(\mathrm{cm})\end{array}$ & $\begin{array}{c}\operatorname{Diam}^{\mathrm{x}} \\
(\mathrm{mm})\end{array}$ & $\begin{array}{c}\text { No. } \\
\text { budsu }\end{array}$ & Symmetry ${ }^{\mathrm{t}}$ & $\begin{array}{c}\text { Needs } \\
\text { pruningw } \\
(\%)\end{array}$ \\
\hline 1 & $100 \mathrm{a}^{\mathrm{s}}$ & $1.0 \mathrm{~b}$ & $21.9 \mathrm{a}$ & $0 \mathrm{a}$ & $0.0 \mathrm{a}$ & $7.06 \mathrm{ab}$ & $4.6 \mathrm{a}$ & $1.00 \mathrm{a}$ & $0 \mathrm{a}$ \\
\hline $2^{r}$ & --- & --- & --- & --- & --- & --- & --- & --- & --- \\
\hline $3 \mathrm{~A}$ & $96 a$ & $1.2 \mathrm{c}$ & $19.8 \mathrm{ab}$ & $5 \mathrm{a}$ & $1.8 \mathrm{~b}$ & $6.40 \mathrm{c}$ & $2.9 \mathrm{bc}$ & $0.98 \mathrm{a}$ & $0 \mathrm{a}$ \\
\hline $3 \mathrm{~B}$ & $85 \mathrm{~b}$ & $1.3 \mathrm{c}$ & $16.0 \mathrm{c}$ & $5 \mathrm{a}$ & $1.3 \mathrm{ab}$ & $5.79 \mathrm{~d}$ & $3.2 \mathrm{~b}$ & $0.92 \mathrm{a}$ & $0 \mathrm{a}$ \\
\hline $4 \mathrm{~A}$ & $0 \mathrm{c}$ & $0 \mathrm{a}$ & $19.2 \mathrm{ab}$ & $36 \mathrm{c}$ & $11.3 \mathrm{~d}$ & $7.45 \mathrm{a}$ & $3.0 \mathrm{bc}$ & $0.56 \mathrm{~b}$ & $12 \mathrm{ab}$ \\
\hline $4 \mathrm{~B}$ & $0 \mathrm{c}$ & $0 \mathrm{a}$ & $18.3 \mathrm{bc}$ & $29 \mathrm{~b}$ & $9.1 \mathrm{c}$ & $6.78 \mathrm{bc}$ & $2.9 \mathrm{bc}$ & $0.63 \mathrm{~b}$ & $100 \mathrm{c}$ \\
\hline 5 & $8 \mathrm{c}$ & $0.1 \mathrm{a}$ & $20.3 \mathrm{ab}$ & $33 \mathrm{bc}$ & $10.5 \mathrm{~cd}$ & $7.07 \mathrm{ab}$ & $2.8 \mathrm{c}$ & $0.52 \mathrm{~b}$ & $19 \mathrm{~b}$ \\
\hline $6^{q}$ & --- & --- & --- & -- & -- & --- & --- & --- & $100 \mathrm{c}$ \\
\hline
\end{tabular}

${ }^{\mathrm{z}}$ Current-year growth of leader or the branch most likely to make a leader.

${ }^{y}$ Angle from vertical (degrees).

${ }^{x}$ Measured in opposite directions $3 \mathrm{~cm}$ above nodal insert.

${ }^{\text {w}}$ Additional pruning to favor the best bud or leader.

vTreatments are described in Table 1.

"Subterminal buds on the leader or most vertical branch.

'Values: $0=$ two-ranked like a branch; $1.00=$ radial symmetry of a leader.

sMean separation within columns by Duncan's multiple range test at $P \leq 0.05 ; \mathrm{n}=25$ plants.

'Treatment 2 was lost due to a mistake in pruning.

qPlants in treatment 6 appeared to have no leaders after the first growing season. 
Table 4. Leader traits for Fraser fir at the end of the first growing season after removal of the terminal bud (Expt. 2)

\begin{tabular}{lccccccc}
\hline \hline & $\begin{array}{c}\text { Leaders }^{\mathrm{z}} \\
(\%)\end{array}$ & $\begin{array}{c}\text { No. } \\
\text { leaders }\end{array}$ & $\begin{array}{c}\text { Length } \\
(\mathrm{cm})\end{array}$ & $\begin{array}{c}\text { Angle }^{\mathrm{y}} \\
\left({ }^{\circ}\right)\end{array}$ & $\begin{array}{c}\text { Offset }^{\mathrm{x}} \\
(\mathrm{cm})\end{array}$ & $\begin{array}{c}\text { No. } \\
\text { buds }^{\mathrm{v}}\end{array}$ & Symmetry $^{\mathrm{u}}$ \\
\hline 1 & $100 \mathrm{a}^{\mathrm{t}}$ & $1.0 \mathrm{~b}$ & $21.9 \mathrm{a}$ & $0 \mathrm{a}$ & $0 \mathrm{a}$ & $4.3 \mathrm{a}$ & $1.00 \mathrm{a}$ \\
2 & $0 \mathrm{c}$ & $0 \mathrm{c}$ & $16.0 \mathrm{bc}$ & $54 \mathrm{~d}$ & $12.6 \mathrm{f}$ & $3.0 \mathrm{~b}$ & $0.16 \mathrm{~cd}$ \\
$3 \mathrm{~A}$ & $88 \mathrm{~b}$ & $1.5 \mathrm{a}$ & $12.7 \mathrm{de}$ & $10 \mathrm{~b}$ & $2.2 \mathrm{~b}$ & $3.0 \mathrm{~b}$ & $0.92 \mathrm{a}$ \\
$3 \mathrm{~B}$ & $88 \mathrm{~b}$ & $1.5 \mathrm{a}$ & $11.1 \mathrm{e}$ & $9 \mathrm{~b}$ & $1.7 \mathrm{~b}$ & $3.1 \mathrm{~b}$ & $0.90 \mathrm{a}$ \\
$4 \mathrm{~A}$ & $0 \mathrm{c}$ & $0 \mathrm{c}$ & $16.6 \mathrm{bc}$ & $39 \mathrm{c}$ & $10.2 \mathrm{~cd}$ & $3.1 \mathrm{~b}$ & $0.36 \mathrm{~b}$ \\
5 & $0 \mathrm{c}$ & $0 \mathrm{c}$ & $17.7 \mathrm{~b}$ & $41 \mathrm{c}$ & $11.4 \mathrm{de}$ & $3.0 \mathrm{~b}$ & $0.26 \mathrm{bc}$ \\
6 & $0 \mathrm{c}$ & $0 \mathrm{c}$ & $14.6 \mathrm{~cd}$ & $40 \mathrm{c}$ & $9.5 \mathrm{c}$ & -- & $0.26 \mathrm{bc}$ \\
7 & $0 \mathrm{c}$ & $0 \mathrm{c}$ & $16.6 \mathrm{bc}$ & $45 \mathrm{c}$ & $11.3 \mathrm{de}$ & $3.1 \mathrm{~b}$ & $0.20 \mathrm{~cd}$ \\
8 & $0 \mathrm{c}$ & $0 \mathrm{c}$ & $16.9 \mathrm{bc}$ & $42 \mathrm{c}$ & $10.9 \mathrm{~d}$ & $3.1 \mathrm{~b}$ & $0.28 \mathrm{bc}$ \\
9 & $0 \mathrm{c}$ & $0 \mathrm{c}$ & $14.8 \mathrm{~cd}$ & $56 \mathrm{~d}$ & $12.4 \mathrm{ef}$ & --- & $0.10 \mathrm{~d}$ \\
\hline
\end{tabular}

${ }^{\mathrm{z}}$ Orthotropic shoots with radial symmetry.

${ }^{y}$ Angle from vertical (degrees).

${ }^{\mathrm{x}}$ Displacement of terminal bud from center axis of tree.

wTreatments are described in Tables 1 and 2.

vSubterminal buds on best leader or most vertical branch.

"Values: $0=$ two-ranked like a branch, $1.00=$ radial symmetry of a leader.

'Mean separation within columns by Duncan's multiple range test at $P \leq 0.05 ; \mathrm{n}=25$ plants.

Table 5. Height and leader traits of Fraser fir Christmas trees two growing seasons after corrective pruning for loss of the terminal bud (Expt. 2).

\begin{tabular}{llcccc}
\hline & & \multicolumn{3}{c}{ Leader } \\
\cline { 3 - 6 } Treatment $^{\mathrm{w}}$ & $\begin{array}{c}\mathrm{Ht}^{\mathrm{z}} \\
(\mathrm{cm})\end{array}$ & $\begin{array}{c}\text { Length } \\
(\mathrm{cm})\end{array}$ & $\begin{array}{c}\text { Angle } \\
\left({ }^{\circ}\right)\end{array}$ & $\begin{array}{c}\text { Offset }^{\mathrm{x}} \\
(\mathrm{cm})\end{array}$ & Symmetry $^{\mathrm{v}}$ \\
\hline 1 & $87 \mathrm{a}^{\mathrm{u}}$ & $25.2 \mathrm{ab}$ & $0 \mathrm{a}$ & $0.3 \mathrm{a}$ & $0.98 \mathrm{a}$ \\
2 & $73 \mathrm{~b}-\mathrm{d}$ & $25.6 \mathrm{ab}$ & $22 \mathrm{~d}$ & $13.2 \mathrm{e}$ & $0.78 \mathrm{~d}$ \\
$3 \mathrm{~A}$ & $73 \mathrm{~b}-\mathrm{d}$ & $20.3 \mathrm{c}$ & $3 \mathrm{a}$ & $1.5 \mathrm{a}$ & $1.00 \mathrm{a}$ \\
$3 \mathrm{~B}$ & $69 \mathrm{~d}$ & $20.3 \mathrm{c}$ & $2 \mathrm{a}$ & $0.8 \mathrm{a}$ & $1.00 \mathrm{a}$ \\
$4 \mathrm{~A}$ & $76 \mathrm{bc}$ & $27.5 \mathrm{a}$ & $15 \mathrm{bc}$ & $9.2 \mathrm{~cd}$ & $0.90 \mathrm{a}-\mathrm{d}$ \\
5 & $75 \mathrm{bc}$ & $25.0 \mathrm{ab}$ & $17 \mathrm{~cd}$ & $10.9 \mathrm{de}$ & $0.89 \mathrm{a}-\mathrm{d}$ \\
6 & $74 \mathrm{~b}-\mathrm{d}$ & $25.0 \mathrm{ab}$ & $11 \mathrm{~b}$ & $6.2 \mathrm{~b}$ & $0.96 \mathrm{ab}$ \\
7 & $74 \mathrm{~b}-\mathrm{d}$ & $25.3 \mathrm{ab}$ & $19 \mathrm{~cd}$ & $11.7 \mathrm{de}$ & $0.81 \mathrm{~cd}$ \\
8 & $76 \mathrm{~b}$ & $26.1 \mathrm{ab}$ & $15 \mathrm{bc}$ & $10.1 \mathrm{~cd}$ & $0.85 \mathrm{~b}-\mathrm{d}$ \\
9 & $70 \mathrm{~cd}$ & $21.8 \mathrm{bc}$ & $15 \mathrm{bc}$ & $8.0 \mathrm{bc}$ & $0.92 \mathrm{a}-\mathrm{c}$ \\
\hline
\end{tabular}

${ }^{\mathrm{z} A f t e r}$ shearing.

${ }^{y}$ Angle from vertical (degrees).

${ }^{x}$ Displacement of terminal bud from center axis of tree.

wTreatments are described in Tables 1 and 2.

vValues: 0 = two-ranked like a branch, $1.00=$ radial symmetry like a leader.

uMean separation within columns by Duncan's multiple range test at $P \leq 0.05 ; \mathrm{n}=25$ plants.

placement leader after the first growing season (1991). Because this technique seemed to have failed, it was not included in Expt. 2. Closer inspection in Spring 1992 revealed that most plants had two or three small shoots (at the top of the 1990 internode) that were becoming orthotropic and had strong buds as on leaders. Most of these new leaders were only 2 or $3 \mathrm{~cm}$ long. In Apr. 1992, the original terminal whorl (1990 node), consisting of branch stubs, was removed, and the largest of these small shoots was retained as a leader. These were some of the best quality trees after 3 years (Table 4 ).

After 3 years in the field (Expt. 1), trees that never lost the terminal bud were tallest and had the most uniform crown density (Table 6, treatment 1). Most other treatments endured a higher incidence of crown defects. Treatment 6 yielded good results despite the loss of $\approx 1$ year of height growth. Young Fraser firs appear "open" for the first few years, and the proportion with gaps and uneven density tends to decrease with age.

Immature branches convert more quickly to leaders than more mature branches if pruned shortly after budbreak. For example, treatments $3 \mathrm{~A}$ and $3 \mathrm{~B}$ (Table 4 ) yielded orthotropic leaders on almost every plant, whereas no control plants (treatment 2) had vertical leaders after the first growing season. The remaining treatments were applied twice later in the growing season. Based on leader angle and offset (Table 4), only treatment 9 (residual branch shortened to a single bud on the upper side) was significantly affected by pruning date; those pruned on 2 July (shoots almost fully elongated but still succulent) straightened better than those pruned on 31 July ( shoots mature and hardening off). The other two pairs of treatments (4A vs. 7 ; and 5 vs. 8 ) were similar in their degree of straightening for both pruning dates.

Response to corrective pruning likely is affected by plant vigor. Vigor was best in Expt. 1 (perhaps owing to larger, more robust plants), causing branches to bend upward more quickly. Douglas fir scions [Pseudotsuga menziesii (Mirb.) Franco] grafted to vigorous rootstocks grow upward in the first growing season, whereas those grafted to weak rootstocks can remain plagiotropic for more than 8 years (Copes, 1980). In our experiments, response was not identical for the two groups of plants, but general conclusions about the effectiveness of treatments were similar. For example, treatments $3 \mathrm{~A}$ and $3 \mathrm{~B}$ restored a vertical leader in most plants in the first year in both experiments, regardless of vigor (Tables 3 and 4 ).

Removing all but one branch in the upper whorl would likely reduce growth in that whorl and induce compensatory growth in the subtending whorl (Little, 1970). Lightly pruning major branches in the next two lower whorls reduces the chance that one or more of these branches will gain dominance and become the new leader. If a shoot loses rank in the dominance hierarchy, it is less apt to become orthotropic and convert to the radial symmetry of a leader. In treatment 9 (Expt. 2; Fig. 2D), which not only thinned the top whorl to one branch but also removed the apical buds of the residual branch, the ability of the residual branch to straighten was reduced further by the loss of apical buds. Ninety percent of these leaders still had branch morphology after the first year (Table 4; symmetry $=0.10$ ). However, most plants in treatment 9 developed orthotropic leaders during the second year but often with a sharply angled sweep (Fig. 2D). The long-term effect on plant quality is unknown.

Corrective pruning must account for tree growth characteristics as well as economics. Shoot elongation of Fraser fir spans 8 to 10 weeks. Shearing is possible throughout the year but is most effective in July or August. The best method for restoring leaders (Treatment $3 \mathrm{~A}$ ) would entail an additional trip through the field in early spring (May). The extra cost would have to be weighed against the value added. Failure to quickly retrain a leader adds $\geq 1$ year to the harvest age of a tree and reduces its quality. Fraser fir commands a premium price, so few trees would have to be affected per unit area of land to justify corrective pruning.

Mechanical methods for holding a shoot upright are commonly used in the Christmastree culture. Methods include using splints and

Table 6. Quality of Fraser fir Christmas trees three growing seasons after corrective pruning treatments for loss of the terminal bud (Expt. 1).

\begin{tabular}{|c|c|c|c|c|}
\hline Treatment $^{\mathrm{w}}$ & $\begin{array}{c}\mathrm{Ht}^{\mathrm{z}} \\
(\mathrm{cm})\end{array}$ & $\begin{array}{c}\text { Gap or } \\
\text { uneven } \\
\text { density } \\
(\%)\end{array}$ & $\begin{array}{c}\text { Trunk } \\
\text { sweep }^{\mathrm{x}} \\
(\%)\end{array}$ & Quality $^{\mathrm{v}}$ \\
\hline 1 & $129 \mathrm{a}^{\mathrm{u}}$ & $35 \mathrm{a}$ & $0 \mathrm{a}$ & $4.2 \mathrm{a}$ \\
\hline $2^{t}$ & --- & --- & --- & --- \\
\hline $3 \mathrm{~A}$ & $119 \mathrm{bc}$ & $81 \mathrm{~b}$ & $4 \mathrm{a}$ & $3.5 \mathrm{bc}$ \\
\hline $3 \mathrm{~B}$ & $119 b c$ & $77 \mathrm{~b}$ & $8 \mathrm{ab}$ & $3.4 \mathrm{bc}$ \\
\hline $4 \mathrm{~A}$ & $120 \mathrm{bc}$ & $73 \mathrm{~b}$ & $38 \mathrm{c}$ & $3.2 \mathrm{c}$ \\
\hline $4 B$ & $118 \mathrm{bc}$ & $69 \mathrm{~b}$ & $15 \mathrm{ab}$ & $3.6 \mathrm{bc}$ \\
\hline 5 & $124 \mathrm{ab}$ & $80 \mathrm{~b}$ & $28 \mathrm{bc}$ & $3.1 \mathrm{c}$ \\
\hline 6 & $112 \mathrm{c}$ & $67 \mathrm{~b}$ & $4 \mathrm{a}$ & $3.7 \mathrm{~b}$ \\
\hline
\end{tabular}

${ }^{\mathrm{z}}$ After shearing.

One or more faces or tiers of the crown differ in density from the average branch characteristics of the entire tree.

xercentage of trees with noticeable curvature or offset of the leader from the central vertical axis.

wTreatments are described in Tables 1 and 2.

'Scale: $0=$ poor, 3 = average, $5=$ excellent.

"Mean separation within columns by Duncan's multiple range test at $P \leq 0.05 ; \mathrm{n}=25$ plants.

Treatment was lost due to a mistake in pruning. 
bent wires (tree trainers or tree stakes) and taping or tying branches in a vertical position, using other branches as support. Early in the elongation period, when shoots are most responsive to treatment, branches of Fraser fir are small and succulent and are broken or bruised easily by a mechanical device. Mature branches are less apt to break, but there is still the problem of uneven bud distribution. Branches typically have only three subterminal buds that are weaker than those differentiated on a leader or a branch turned upward early in the growing season. Suitable pruning of the upturned branch minimizes defects such as gaps, open tiers, and trunk sweep.
After loss of the terminal bud in Fraser fir, a leader can be established using either pruning techniques alone or various mechanical methods. For best tree quality, corrective pruning should occur soon after budbreak, which allows the tree to develop a new leader during the first growing season. This goal is achieved by removing the apical node and lightly pruning major branches in the next two lower whorls (treatment 3A; Fig. 1C). One or more lateral shoots just below the apical node becomes orthotropic during the first growing season. The strongest new leader can be retained when the tree is sheared late in the growing season.

\section{Literature Cited}

Copes, D.L. 1980. Effect of rootstock vigor on leader elongation, branch growth, and plagio-tropism in 4- and 8-year-old Douglas fir grafts. Tree Planters' Notes 31(4):11-14.

Little, C.H.A. 1970. Apical dominance in long shoots of eastern white pine. Can. J. Bot. 48:239-253.

Powell, G.R. 1982. Shoot and bud development in balsam fir: Implications for pruning of Christmas trees. For. Chronicles 58:168-172.

SAS Institute. 1990. SAS/STAT user's guide. vol. 2. SAS Institute, Cary, N.C.

Shelton, J.E. 1983. Fertilizing Fraser fir Christmas trees. North Carolina Agr. Ext. Serv., Christmas Tree Notes CTN-010.

U.S. Dept. of Agriculture. 1989. United States standards for grades of Christmas trees. Agr. Mktg. Serv. 9. 